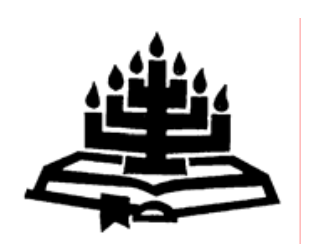

\title{
'n Sosiaal-psigologiese perspektief op lidmate in die Mangaung-area se houding teenoor kerkvereniging in die Nederduitse Gereformeerde Kerkfamilie: 'n kruiskulturele ondersoek
}

\author{
P. Jonck \& A. le Roux \\ Departement Sielkunde \\ Universiteit van die Vrystaat \\ BLOEMFONTEIN \\ E-pos: petrojonck@hotmail.com \\ lerouxa.hum@ufs.ac.za \\ P. Verster \\ Departement Sendingwetenskap \\ Universiteit van die Vrystaat \\ BLOEMFONTEIN \\ E-pos: versterp.hum@ufs.ac.za
}

\begin{abstract}
A social-psychological perspective on the attitude of members in the Mangaung area towards church unification within the Dutch Reformed family of churches: a cross-cultural investigation

Until recently, only one investigation had been conducted into church members' attitudes towards church unification. This was done from a theological instead of a social-psychological point of view. The term "attitude" may be defined as the expression of inner feelings that reflect whether the person concerned has a favourable or unfavourable predisposition towards a certain object. Church unification entails the process of uniting separate church denominations within the Dutch Reformed Church family. The aims of this study were achieved by gathering data from respondents of six Dutch Reformed congregations $(N=104 ; 46,6 \%)$, as well as six Uniting Reformed congregations ( $N=47 ; 21,1 \%)$. The remainder of the respondents came from five Dutch Reformed Church in Africa congregations ( $N=72 ; 32,3 \%)$. A biographical questionnaire
\end{abstract}


was used, as well as the Attitude towards Church Unification Scale. The influence of different variables such as language, gender, age, marital status and church activities on the attitudes of church members was investigated. It was concluded on the basis of statistical analysis that members of all the different denominations of the Dutch Reformed Churches had a positive attitude towards church unification. It was found that language was the variable that had the greatest influence on the attitude of church members.

\section{Opsomming}

\section{'n Sosiaal-psigologiese perspektief op lidmate in die Mangaung-area se houding teenoor kerkvereniging in die Nederduitse Gereformeerde Kerkfamilie: 'n kruiskulturele ondersoek}

Tot dusver is slegs een ondersoek gedoen na lidmate se houding teenoor kerkvereniging. Die uitgangspunt van hierdie artikel is vanuit ' $n$ teologiese en nie 'n sosiaal-psigologiese oogpunt nie. "Houding" word gedefinieer as daardie uitdrukking van 'n persoon se innerlike gevoel wat reflekteer of die persoon 'n gunstige of ongunstige predisposisie het met betrekking tot 'n bepaalde objek. Kerkvereniging behels die proses van samevoeging van verskillende kerkverbande binne die Nederduitse Gereformeerde Kerkfamilie tot een gesamentlike kerkverband. Die doelwitte van die studie is bereik deur inligting van verskeie respondente, afkomstig van die verskillende kerkverbande in die Nederduitse Gereformeerde Kerkfamilie in die Mangaung-area te bekom. Ses Nederduitse Gereformeerde Kerkgemeentes $(N=104 ; 46,6 \%)$, ses Verenigende Gereformeerde Kerkgemeentes ( $N=47 ; 21,1 \%)$, en vyf gemeentes van die Nederduitse Gereformeerde Kerk in Afrika ( $N=72 ; 32,3 \%)$, is by die ondersoek betrek. 'n Biografiese vraelys sowel as die Houding teenoor Kerkvereniging-skaal is gebruik. Die invloed van 'n aantal veranderlikes, naamlik huistaal, geslag, ouderdom, huwelikstatus en kerklike betrokkenheid op lidmate se houding teenoor kerkvereniging is ondersoek. Statistiese ontleding het aangedui dat lede van die NGK-familie deurgaans 'n positiewe houding teenoor kerkvereniging openbaar. Daar is verder gevind dat huistaal die grootste invloed op kerklidmate se houding teenoor kerkvereniging uitoefen.

\section{Inleiding}

Met die "waterskeidingtoespraak" van Staatspresident De Klerk in Februarie 1990 tydens die opening van die parlement, het SuidAfrika ' $n$ beslissende era in sy geskiedenis betree. Die oorgang na politieke demokrasie is een van verskeie sosiopolitieke kwessies 
waarmee Suid-Afrika tans worstel. In hierdie verband het die psigologie as helpende professie 'n betekenisvolle bydrae te lewer. Sosiale psigologie as vakgebied behels die studie van sosiale verskynsels, soos die invloed van die sosiale omgewing op die gedrag van sowel die individu as van groepe. Verder stel dit ook ondersoek in na groepsdinamika, die openbare mening, houdings en vooroordeel (Plug et al., 1997:352). Vooroordeel is 'n destruktiewe aspek van sosiale gedrag en gee dikwels aanleiding tot verontregting wat gebaseer is op ras, geslag en talle ander faktore (Taylor, Peplau \& Sears, 2003:168).

Ook die kerk en sy lidmate word deur hierdie sosiopolitieke kwessies geraak (Coetzee, 2004:7; Potgieter, 1994:1). Die manifestering hiervan, veral in kerklike verband, is byvoorbeeld te vinde in die rassismeklag wat by die Menseregtekommissie ingedien is omdat bruin mense blykbaar steeds uitgesluit word van kerkvergaderings op Parys (Oosthuizen, 2004a:1). In 'n land wat geteister word deur vooroordeel en rassisme is dit noodsaaklik om daadwerklike pogings aan te wend om welwillendheid en versoening in die hand te werk. Kennis van vooropgestelde houdings teenoor kerkvereniging kan lei tot die uitbreiding van wetenskaplike kennis.

\section{Doel van die artikel}

Die samevoeging van "Nkosi Sikelel'iAfrika" en "Die Stem" staan in die teken van versoening. Wat voorheen as onmoontlik beskou is dié twee liedere as een lied hartlik saamgesing deur swart en wit het 'n werklikheid geword in 'n land waar vasberade pogings aangewend word om hande te vat en brûe te bou oor die skynbare onoorbrugbare kloof wat gemeenskappe van mekaar skei (Anon., 2003:6). In die lig van die groot veranderings wat tans in Suid-Afrika plaasvind, kan algemene sowel as spesifieke doelwitte vir die navorsing wat in hierdie artikel vervat is, geïdentifiseer word. Die algemene doel is om te bepaal wat lidmate van die NGK-familie se houding teenoor kerkvereniging is. Die spesifieke doelwitte hou verband met 'n ondersoek na die veranderlikes wat lidmate se houding teenoor kerkvereniging moontlik beïnvloed. 


\section{Konseptualisering van veranderlikes}

\subsection{Houding}

\subsubsection{Definiëring van die begrip houding}

Die term houding kan gedefinieer word as daardie uitdrukking van 'n persoon se innerlike gevoel wat reflekteer of die persoon 'n gunstige of ongunstige predisposisie het met betrekking tot 'n bepaalde objek (Robbins, 1998:140). Eagly en Chaiken (1993) maak volgens Van Rooyen (2002:31) gebruik van die term psigologiese neiging. Psigologiese neiging verwys na 'n interne toestand wat 'n individu predisponeer tot 'n bepaalde evaluerende respons. Die term predisponeer impliseer dat houdings aangeleer of afgeleer, blywend of veranderlik, en belangrik of onbelangrik kan wees. Evaluering verwys na alle soorte evaluerende response, insluitende kognitiewe, affektiewe en gedragsevaluerende response (Taylor et al., 2003:133).

Kognitiewe response behels intellektuele beredenering en derhalwe die oortuiging dat die houdingsobjek oor bepaalde kenmerke beskik en dat gedrag wat hiermee verband hou, tot spesifieke uitkomste sal lei (Schiffman \& Kanuk, 1997:239). Houdings integreer/dra ook herinnerings aan gebeure wat met die houdingsobjekte verband hou, psigiese voorstellings daarvan, en ander fasette van kognisie. Affektiewe response verwys na emosies wat met die houdingsobjek verbind kan word. Individuele waardes, ervarings en emosies lei daartoe dat die objek óf in 'n positiewe lig óf in 'n negatiewe lig geëvalueer word (Potgieter, 1994:40). Houdings fasiliteer die bereiking van geïdentifiseerde doelwitte enersyds en die vermyding van onaangename gebeure andersyds. Konatiewe response hou verband met die neiging van die individu om 'n spesifieke handeling met betrekking tot die houdingsobjek te onderneem (Schiffman \& Kanuk, 1997:240).

\subsubsection{Funksies van houdings}

Houdings is dikwels 'n uitdrukking van mense se waardes. Houdings wat kongruent is met ' $n$ persoon se sentrale waardes word geïnternaliseer, en sodoende word bevrediging verkry wat tot die verbetering van die persoon se selfbeeld bydra. Houdings vervul ook die funksie van verdedigingsmeganismes en dra by tot die beskerming van die ego teen kritiek. Impulse en kwaliteite wat afkeurenswaardig is, word verwerp en op die buitewêreld geprojekteer (Van Rooyen, 2002:31). Die kern van instrumentele 
houdings is die waarde wat 'n persoon aan bepaalde houdings heg: beloning word nagestreef en straf vermy. Die vorming van instrumentele houdings word bepaal deur die individu se evaluering van die betrokke voorwerp as synde voordelig of nadelig (Schiffman \& Kanuk, 1997: 262; Van Rooyen, 2002:31).

Die mensdom streef voortdurend na kennis om die wêreld te organiseer en te klassifiseer om sodoende 'n groot verskeidenheid prikkels te kontroleer. Derhalwe word 'n stelsel van opinies, houdings en waardes benodig waarvolgens individue gedrag, idees en resultate beoordeel kan word, en wat 'n rigtinggewende invloed op gedrag en denke kan uitoefen (Plug et al., 1997:401; Van Rooyen, 2002:31). Die tipe houdings wat ingeneem word, is 'n aanduiding van die gedrag wat daaraan verwant is (Potgieter, 1994:46).

\subsubsection{Die verband tussen houdings en gedrag}

Daar is 'n sterk verwantskap tussen sekere soorte gedrag en houdings (Van Rooyen, 2002:44). Weens situasionele druk (Stephan \& Stephan, 1990:259; Taylor et al., 2003:163) of sosiale norme is daar in sekere situasies beperkte keuses ten opsigte van die gedragspatroon wat gemanifesteer kan word. Sekere persoonlikheidsfaktore beïnvloed ook die verhouding tussen houdings en gedrag. Een van hierdie persoonlikheidsfaktore is selfmonitering. Selfmonitering verwys na die mate waarin mense eerder op interne as op eksterne leidrade staatmaak wanneer dit by die bepaling van gedrag kom. Diegene wat lae vlakke van selfmonitering uitoefen, tree volgens houdings, waardes en idees op. Ander persone tree weer volgens eksterne leidrade op. Hulle gedrag word deur die norme, waardes en gedrag van ander mense bepaal (Van Rooyen, 2002:45; Worchel et al., 2000:148).

Intrinsieke en ekstrinsieke motivering is ' $n$ addisionele persoonlikheidsveranderlike wat die verband tussen houdings en gedrag beïnvloed. In die geval van 'n godsdienstige oriëntasie sal diegene wat intrinsiek gemotiveer word godsdienstige waardes soos nederigheid, empatie en naasteliefde internaliseer. Hierdie waardes dien as 'n verwysingsraamwerk waarvolgens gebeure geïnterpreteer kan word. Ekstern gemotiveerde individue laat hulle lei deur die bruikbaarheid van godsdienstige houdings, wat weer aanleiding gee tot die aanhang van ideologieë wat groepsbelange bevorder (Kirkpatrick \& Hood, 1990:444). 


\subsubsection{Die verband tussen houdings en groep-antagonisme}

Groep-antagonisme toon verskeie konseptuele raakpunte met die term houding. Groep-antagonisme kom voor wanneer lede van 'n binnegroep negatiewe houdings teenoor lede van 'n buitegroep openbaar. Antagonisme het drie onderling verbandhoudende elemente. Stereotipes behels die kognitiewe oortuiging dat groeplede oor bepaalde en kenmerkende karaktereienskappe beskik. Vooroordeel verwys na die affektiewe dimensie wat 'n ongunstige predisposisie jeens 'n teikengroep reflekteer. Diskriminasie hou verband met die neiging van die individu om spesifieke handelinge, wat tot nadeel van die teikengroep strek, uit te voer. Hier gaan dit om die konatiewe respons op 'n bepaalde houding (Taylor et al., 2003:170).

Verskeie navorsingstudies toon 'n verband aan tussen vooroordeel, as synde die affektiewe komponent van 'n ongunstige houding, en godsdienstige oortuigings (Jackson \& Hunsberger, 1999:509; Kirkpatrick \& Hood, 1990: 442).

\subsubsection{Vooroordeel en godsdienstige oortuigings}

Sosiale interaksie binne 'n bepaalde groep word beskou as voorspelbaar en wedersyds voordelig. Soos wat die binnegroep egter groei en verhoudings meer onpersoonlik raak, neem instellings, reëls en gebruike wat binnegroep-lojaliteit en -samewerking as doelwit het, 'n godsdienstig-outoritêre karakter aan. Indien godsdienstige voorskrifte as absoluut (onbetwisbaar) beskou word, word geboorte geskenk aan godsdienstige superioriteit. Godsdienstige superioriteit verskaf regverdiging asook legitimasie vir die onderdrukking van die buitegroep. 'n Groot aantal diskriminerende persepsies en handelinge word primêr gemotiveer deur die begeerte om positiewe binnegroep-verhoudings te handhaaf en te bevorder. Die negatiewe evaluering van die buitegroep lei nie noodwendig tot direkte antagonisme en konflik nie. Die wedersydse verhouding tussen binnegroep-kohesie en buitegroep-antagonisme word beïnvloed en bepaal deur omstandighede/situasies waarin groepe meeding om skaars hulpbronne en/of politieke mag (Brewer, 1999:435).

Die werking van politieke kragte het 'n oorweldigende rol gespeel in die eenheid van die NGK. Die volksverbondenheid van dié kerk was so groot dat teologiese beslissings oor maatskaplike sake nie primêr op grond van 'n objektiewe uitleg van die Skrif geneem is nie, maar ten nouste verbonde was aan politieke oortuigings asook die 
handhawing van die reg (Jonker, 1998:13). Vervolgens gaan die soeklig val op 'n kort historiese oorsig van die ontstaan van die afsonderlike NG Kerke, asook die veranderings wat plaasgevind het nadat apartheid as politieke ideologie in Suid-Afrika gesneuwel het.

\subsection{Kerkvereniging}

Die Drie Formuliere van Eenheid, as erkende belydenisskrifte, is die basis onderliggend aan kerklike gemeenskap in die Nederduitse Gereformeerde Kerkverband. Dit het onder andere betrekking op dit wat oor eenheid in die Nederlandse Geloofsbelydenis én die Heidelbergse Kategismus bely word. Volgens die formuliere wat die gemeenskaplike geloof van hierdie kerke verwoord, is dit Christus wat sy kerk deur sy Woord en Gees in die eenheid van die ware geloof van die begin tot die einde vergader, beskerm en onderhou. Op dieselfde noot word verklaar dat almal verplig is om die eenheid van die kerk te bewaar deur hulle aan die leer en tug van Christus te onderwerp. Dit gaan dus om 'n eenheid in waarheid, soos deur God in sy Woord geopenbaar, 'n eenheid in belydenis bewerkstellig deur die Heilige Gees; dit gaan om 'n belydenis oor God-Drie-enig asook die Almagtige se verhouding met die mensdom (Strauss, 2005:1). Prinsipieel kan kerkeenheid dus beskou word as die kerk van oorsprong wat een is in God-Drie-enig. Hierdie eenheid moet te midde van verskeidenheid in God se skepping en in die verskeurde werklikheid sigbaar gemaak word. Kerkvereniging behels gevolglik die proses van samevoeging van die verskillende kerkverbande tot een gesamentlike kerkverband (Hofmeyr, 1996:330).

\subsubsection{Ontstaan van die NG Kerk in Suid-Afrika}

Die ontstaansjaar van die NG Kerk val saam met die historiese aankoms van Jan van Riebeeck aan die Kaap in 1652. Vir die eerste 200 jaar van sy bestaan was die NG Kerk één kerk (Hofmeyr, 1996:331; Van der Linde, 2002:35). Uit die geskiedenis blyk dit dat daar vrae ontstaan het ten opsigte van die gesamentlike gebruik van die Nagmaal. Al was dit die oortuiging dat die belydenis van die gemeenskap van heiliges vereis dat saam aan die tafel van die Here gesit moet word, is besluit dat as oorgangsmaatreël daar tog verskillende Nagmaalsvierings toegelaat mag word, "vanweë die swakheid van sommige". Wat as oorgangsmaatreël vir 'n beperkte tyd bedoel was, het algaande praktyk geword. Afsonderlike dienste vir die onderskeie rassegroepe het mettertyd tot die stigting van afsonderlike kerke gelei (Hofmeyr, 1996:331; Van der Linde, 2002:18). 


\subsubsection{Nederduitsche Gereformeerde Zendingkerk}

Die afbakening van die arbeidsterrein ten opsigte van die bearbeiding van anderskleuriges het voortdurend in die teken van verwarring, oorvleueling en onsekerheid gestaan (Van der Linde, 2002:70). Die bestaan en funksionering van anderskleurige gemeentes sou nie anders gehandhaaf kon word nie as langs die weg van samevoeging tot een liggaam, naamlik in 'n afsonderlike kerk (Smith, 1972:76). Die sosiale onaanpasbaarheid tussen blank en nie-blank, asook nie-blankes onderling, het gelei tot die gevoel dat gedwonge gesamentlike kerklike byeenkomste nadelig vir die saak van Christus sou wees (Smith, 1972:41-42).

In 1857 het die NG Kerk amptelik van die standpunt uitgegaan dat daar afsonderlike gemeentes vir nie-blankes behoort te wees (Van der Linde, 2002:72). In die soeke na 'n praktiese metode om die evangelie aan mense van wyd uiteenlopende taal- en kultuuragtergronde te verkondig, is die ontwikkeling van aparte lewenskringe as 'n ideale oplossing beskou. So sou nie-blankes kerklik, op eie terrein en in ooreenstemming met hulle eie aard en aanleg kon groei tot selfstandigheid (Adonis, 2002:336; NGK, 1974:3). Drie-en-twintig jaar na die besluit in 1857 het 'n hele aantal gemeentes tot stand gekom en daar was 'n groeiende belangstelling in die skep van 'n breër kerkbestuur. Weens die behoefte van sendelinge om 'n raad te hê waarop hulle hulself kon beroep, word 'n sinvolle/funksionele kerklike organisasie vir sendingwerk bepleit (Van der Linde, 2002:72). Die NG Sendingkerk is in 1881 gestig as "kleurlingkerk" (Adonis, 2002:328).

\subsubsection{Nederduitse Gereformeerde Kerk in Afrika}

Indrukwekkende en omvangryke sendingwerksaamhede, wat deur min kerke in hierdie periode geëwenaar kon word, is deur individuele NGK-gemeentes onderneem. Die NG Kerk in Afrika is as afsonderlike provinsiale kerke op verskillende tye gestig. Die NG Sendingkerk van die Oranje-Vrystaat is in 1910 gestig, die NG Sendingkerk van Transvaal in 1932, die NG Bantoekerk in SuidAfrika in 1951 (Kaapland) en die NG Sendingkerk van Natal in 1952. In 1963 het hierdie vier sendingkerke in Kroonstad in een kerkverband verenig onder die naam die NG Kerk in Afrika (Adonis, 2002:328).

\subsubsection{Reformed Church in Africa}

Die Indiërbevolking in Suid-Afrika het teen 1965 gegroei tot 533000. Aangesien die blanke bevolking van mening was dat die 
Indiërbevolking na hulle geboorteland moes terugkeer, het bykans tagtig jaar verloop alvorens daar amptelik met sendingwerk onder Indiërs begin is (Smith, 1972:121; Van der Linde, 2002:84). In 1966 word 'n konsep-kerkorde vir die stigting van 'n Indiërkerk aanvaar, wat ná enkele wysigings in Augustus 1968 as basis vir die vereniging van gemeentes in een kerkverband aanvaar is. Die Reformed Church in Africa het sy beslag gekry (Van der Linde, 2002:86). Weens die sendingarbeid van die NG Kerk is nie minder nie as vyftien jonger kerke gestig tussen 1881 en 1985 (Hofmeyr, 1996:332; Van der Linde, 2002:87).

\subsubsection{Apartheid en kerklike beleid}

Die sendingbeleid wat deur die NG Kerk gevolg is, is gekenmerk deur ondersteuning vir aparte maatskaplike en ekonomiese ontwikkeling (Adonis, 2002:329), mits dit in liefde en op 'n regverdige grondslag toegepas word. Die sendingbeleid was dus identies aan rasseskeiding, wat ook later as politieke beleid aanvaar is (Adonis, 2002:329). Die ideologiese denkrigting van die dertigerjare is vanaf 1948 polities geïmplementeer toe die Nasionale Party aan bewind gekom het (Van der Linde, 2002:125). In die verlede was daar 'n noue verbintenis tussen sending en apartheid. Volgens Hanekom, die bekende kerkhistorikus, kan daar met reg gepraat word van apartheid as 'n kerklike beleid (vgl. Adonis, 2002:335). Lank voordat hierdie vraagstuk op maatskaplike gebied enigsins problematies was, is die erns daarvan in kerklike kringe aangevoel en is 'n geskikte oplossing daarvoor gesoek. Weens die uiteenlopendheid van taal- en kultuuragtergronde, moes praktiese metodes gevind word sodat elkeen volgens sy eie aard die groot dade van God kon hoor en verkondig (NGK, 1974:3). Die ideale oplossing is gevind in die ontwikkeling van aparte lewenskringe sodat nie-blankes kerklik, op eie terrein en in ooreenstemming met hulle eie aard en aanleg kon groei tot selfstandigheid (Adonis, 2002:336).

\subsubsection{Politieke woelinge}

Dat vernuwing noodsaaklik was, was teen die sestigerjare duidelik nadat die gebeure by Sharpeville Suid-Afrika in ' $n$ toestand van grootskaalse paniek gedompel het. Dit was egter die wêreldwye ongunstige publisiteit wat kerkleiers gedwing het om die verhoudingsproblematiek in 'n veelvolkige land te heroorweeg (Van der Merwe, 1990:11-12). 


\subsubsection{Ras, volk en nasie en volkereverhoudinge in die lig van die Skrif}

Volgens die beleidstuk van die NGK, naamlik Ras, volk en nasie en volkereverhoudinge in die lig van die Skrif, is daar geen eksklusiewe volkse kerk in dié sin dat gelowiges uit ander volke nie daarby mag aansluit nie, al word die belangrikheid van die volkseie vir die kommunikasie van die Christelike evangelie en die belewing van die gemeenskap van heiliges gehandhaaf. 'n Aparte kerk is nog geen geslote kerk nie (NGK, 1974:47). Regverdiging vir afsonderlikheid is soos volg verwoord: "In die verkondiging van die Evangelie aan mense van wyd uiteenlopende taal en kultuur is daar praktiese metodes gevind sodat elkeen in sy eie taal die groot dade van God kon hoor en verkondig" (NGK, 1974:3).

\subsubsection{Die Wêreldbond van gereformeerde kerke}

Die Wêreldbond van gereformeerde kerke is die grootste gereformeerde ekumeniese liggaam. In Augustus 1982 het die Wêreldbond in Ottawa vergader. Die gevolgtrekking waartoe gekom is, was dat apartheid as sonde beskou word, en dat morele en teologiese regverdiging daarvan 'n karikatuur van die evangelie daarstel (Adonis, 2002:337; Van der Linde, 2002:168).

\subsubsection{Die NG Sendingkerk verwoord verdeeldheid}

In 1982 neem die NG Sendingkerk die besluit dat die sekulêre evangelie van apartheid die belydenis van versoening en die eenheid van die kerk in sy wese bedreig. Daar word besluit om 'n belydenis op te stel waarin dié kerk opnuut sy geloof bely. Die resultaat was die Belydenis van Belhar van 1986 (Adonis, 2002:337). Alhoewel die kerk uit mense van verskillende rasse en kulture bestaan, snoer die Heilige Gees hulle saam in een liggaam. Enigiets "wat dié eenheid bedreig" mag "geen plek in die kerk van Christus" hê nie. Enige leer wat gedwonge skeiding wil legitimeer en dit nie wil waag op die pad van gehoorsaamheid en versoening nie, verloën die versoenende krag van die evangelie (Wessels, 2004:9).

\subsubsection{Koersverandering skep 'n nuwe klimaat vir eenheid}

Sedert die tagtigerjare het die NG Kerk homself telkemale in 'n posisie bevind waar die volgehoue beleid van afsonderlike ontwikkeling verdedig moes word. Die NG Kerk moes derhalwe sy eie teologie in oënskou neem (Van der Linde, 2002:182). 


\subsubsection{Kerk en samelewing, 1986}

Pogings om die beleid van die NG Kerk te verander, het in 1986 momentum begin kry. Volgens die beleidstuk Kerk en samelewing 'n getuienis van die NG Kerk vorm die NG Kerk deel van God se unieke, heilige, uitverkore volk te midde van die nasies (NGK, 1986:42). Die familie van NG Kerke is kragtens hulle gemeenskaplike historiese oorsprong, geloof en verbondenheid aan dieselfde Here, asook hulle erkenning van die gereformeerde belydenis, wesenlik één, alhoewel daar op institusionele vlak 'n onderskeid tussen hulle getref kan word (NGK, 1986:44).

Paragraaf 270 in bogenoemde beleidskrif artikuleer die belangrike besluit om die deure vir elkeen wat die leer van die NG Kerk bely, ongeag ras, oop te stel. Volgens paragraaf 265 is geloof in die Drieenige God, sy openbaring in die Skrif en die verwoording hiervan in die aanvaarde belydenisskrifte die enigste voorwaarde om aan die kerk van Christus te behoort (Coertzen, 2000:186; NGK, 1986:4546). In paragraaf 112 verklaar die Sinode dat rassisme 'n sonde is; dit word beskou as iets wat veragting en haat vir jou naaste in die hand werk en 'n struikelblok in die weg lê vir hom/haar om hulle roeping in God te verwesenlik. Enige persoon wat deur houding of handeling aandui dat een ras, persoon of groep inherent verhewe is bo ' $n$ ander ras, persoon of groep, of inherent ondergeskik is, maak homself skuldig aan rassisme (Coertzen, 2000:186; NGK, 1986:22).

Aanvaarding van hierdie beleidstuk het daartoe gelei dat 'n groep lidmate die NG Kerk verlaat het en hulle eie kerk, die Afrikaanse Protestantse Kerk, gestig het (Coertzen, 2000:186). 'n Verdere groep het besluit om aan te bly ten einde die beleidstuk tydens die Algemene Sinode in 1990 tot niet te maak (Potgieter, 1994:9).

\subsubsection{Kerk en samelewing, 1990}

Tydens die sinodesitting van 1990 is die hersiene stuk, naamlik Kerk en samelewing (1990), goedgekeur. Terwyl die NG Kerk plegtig en met volharding die wil van God nagestreef het, word erken dat die Kerk verkeerd was om die geforseerde skeiding van mense te beskou as 'n Bybelse imperatief. Die NG Kerk moes hulle vroeër gedistansieer het van hierdie siening en bely hulle nalatigheid in dié verband (Coertzen, 2000:187). Opregte bedoelings ten opsigte van die optimale ontwikkeling van alle bevolkingsgroepe binne hulle eie kulturele tradisie was egter die dryfkrag agter die beleid van afsonderlike ontwikkeling. In beginsel moet die reg van volkere om hulle eie kulturele waardes te bewaar, erken word as behorend tot 
die mens, mits die Bybelse eise van naasteliefde nie in die gedrang kom nie (Potgieter, 1994:24-25).

\subsubsection{1994: "Sinode van versoening"}

Tydens die Algemene Sinode van 1994 het die proses van verandering verdere stukrag verkry toe besluit is om gesamentlik te werk aan die opstel van 'n nuwe kerkorde vir één kerkverband. Ook word onderneem om onder andere aandag te skenk aan sake soos die naam van die voorgestelde nuwe kerkorde en die werkswyse van 'n enkele kerkverband (NGK, 1994:354-355; Hofmeyr, 1996:333).

\subsubsection{Kerkvereniging tussen twee lede van die familie word 'n werklikheid}

Intussen het die NG Sendingkerk en die NG Kerk in Afrika met hulle eie proses van kerkvereniging voortgegaan en die Verenigende Gereformeerde Kerk in Suider-Afrika het in 1994 sy beslag gekry (Adonis, 2002:338). Van die begin af was sommige gemeentes van die NG Kerk in Afrika egter nie gediend met dié vereniging nie. Pogings om geskille op te los, het misluk en het daartoe gelei dat 'n aansoek by die Hooggeregshof ingedien is (Van der Linde, 2002:228). Die beslissing van die Appèlhof was dat die Algemene Sinode van die NG Kerk in Afrika in Julie 1991 sy magte oorskrei het. Die voortgesette bestaan van die NG Kerk in Afrika is erken en die kerk kon weereens sy regsbevoegdheid uitoefen (Van der Linde, 2002:231-232). Betrekkinge tussen dié twee kerke, veral ná die hofuitspraak, het die verwerkliking van eenwording bemoeilik (Coertzen, 2000:193-194).

\subsubsection{Knelpunte in die kerkverenigingsproses}

Gesprekke tussen lede van die NGK-familie oor kerkeenheid wissel van optimistiese dialoog wat groei en eenheid in die vooruitsig stel tot vergaderings waar dooiepunte bereik word en verdeeldheid na vore tree (Van der Linde, 2002:191, 251). Die hele proses het geleidelik in 'n slakkepas verval - in so 'n mate dat die Algemene Sinode van die NG Kerk sy hartseer en verleentheid uitgespreek het omdat daar na baie jare se gesprekke nie veel vordering gemaak is nie (Anon., 2004a:6).

\subsubsection{Verskille oor die Belydenis van Belhar}

Die Belydenis van Belhar wat in 1986 as belydenisskrif in die Verenigende Gereformeerde Kerk aanvaar is, het waarskynlik die 
steen des aanstoots geword in die vurige debat oor kerkvereniging (Van Niekerk, 1996:443). Alhoewel die Algemene Sinode van die NG Kerk reeds in 1998 die wesenlike inhoud van dié belydenis aanvaar het, is dit nie as vierde belydenisskrif aanbeveel nie (Wessels, 2004:9). Sommige mense het besware teen dié omstrede belydenis. Reformatore verskaf met 'n belydenisskrif 'n samevatting van die essensiële inhoud van die Christelike geloof soos hulle dit sien. Teen die agtergrond van die inhoud van die Belhar-belydenis glo sommige mense dat dié polemiese belydenis 'n eties-politieke probleem tot 'n belydeniskwessie verhef (Strauss, 2005:14).

Die Algemene Sinode van 2002 het aanvaar dat daar voorsiening moet wees vir die opname van dié tendensieuse geskrif in die belydenisgrondslag van die nuwe kerk. Al sou dit aanvaar word as 'n belydenisskrif, moet geen gemeente gedwing word om dit te onderskryf nie (Wessels, 2004:9). Kerkrade behou egter die besluitnemingsbevoegdheid oor die inrigting van hulle gemeentes (Anon., 2004a:6). Die Verenigende Gereformeerde Kerk het die besluit van die NG Kerk se Algemene Sinode dat die Belydenis van Belhar 'n opsionele geloofsbelydenis moet wees, onomwonde verwerp (Oosthuizen, 2004b:3). Die NG Kerk het ook bande met die NG Kerk in Afrika én die Reformed Church of Africa, wat nie een die Belydenis van Belhar volledig as belydenisskrif aanvaar het nie (Anon., 2004a:6).

\subsubsection{Die "Albatros-sindroom" van apartheid}

Die NG Kerk het 'n bydra gelewer tot die regverdiging van apartheid as 'n Skrifgefundeerde politieke en kerklike model. Die invloed wat hierdie stormagtige geskiedenis op die lewens van mense gehad het, sal nooit volledig begryp kan word nie. Apartheid het ' $n$ onuitwisbare indruk gemaak op elke persoon wie se lewe daardeur geraak is. In vele opsigte het dit 'n soort albatros geword wat (steeds) om mense se nekke hang (Van der Linde, 2002:298).

\section{Die perspektief van lidmate}

Hierdie artikel poog om 'n kruiskulturele weergawe te bied van lidmate van die familie van NG Kerke se houding teenoor kerkvereniging. Vervolgens word enkele lidmate se houdings weergegee. De Beer van die Reformed Church of Africa het die hoop uitgespreek dat die eenwordingsproses so gou as moontlik op dreef sal kom (Oosthuizen, 2004c:1). Lebone van die NG Kerk in Afrika het sy dank uitgespreek dat dié kerk na 'n lang tyd weer deel kan wees van die eenheidsgesprek (Oosthuizen, 2003:6). In 
teenstelling hiermee beweer Erasmus, die vorige moderator van die NG Kerk in die Vrystaat, dat 60\% van NGK-mense na die wortels van dié kerk se tradisie soek (Sauer, 2005:1). Op gemeentevlak is daar volgens 'n plaaslike leraar van die Verenigende Gereformeerde Kerk verskeie struikelblokke wat nie onoorkombaar is nie, nieteenstaande die feit dat die verlede die onderskeie kerke baie ver uit mekaar gedryf het. Dienooreenkomstig het lidmate van die NG Kerk in Afrika die behoefte uitgespreek dat gespreksgenote aan hulle geloofsfondamente geanker sal wees en dat die fundamentele leerstellings van die Christelike geloof die middelpunt van gesprekvoering sal vorm.

\section{Faktore wat die houding teenoor kerkvereniging beïnvloed}

Ten einde die doelwit van hierdie artikel te bereik, sal aandag geskenk word aan gekose demografiese veranderlikes wat moontlik 'n impak het op lidmate se houding teenoor kerkvereniging.

\subsection{Huistaal}

Die vermoë om jouself verstaanbaar uit te druk, is slegs een van die eienskappe wat eie is aan elke kultuur, maar die vraag ontstaan of daar ' $n$ onderlinge verband is tussen kultuur, taal en denke (Weiten, 2002:241). Benjamin Lee Whorf (Weiten, 2002:242) is 'n prominente ondersteuner van linguistiese relatiwiteit, dit wil sê die hipotese dat taal denke bepaal. Whorf spekuleer dat die voorkoms van verskillende tale daartoe aanleiding gee dat mense verskillende opvattings huldig aangaande houdingsobjekte (Weiten, 2002:242). Volgens Nel (2003:105) is die taal van die NG Kerk onverstaanbaar en leraars spreek nie deur hulle prediking mense in hulle eie leefwêreld aan nie. Barnard (1981:4) wys daarop dat hierdie taal die onbegryplike taal van geleerdes is en dat dit daarbenewens ook kultuurvreemd is.

\subsection{Ouderdom}

Navorsing dui daarop dat sommige van die teorieë oor die verband tussen ouderdom en houdings wel meriete het. Die sosialiserende invloed wat individue ervaar wanneer hulle jonk is, oefen 'n besliste invloed uit op die wyse waarop hulle dink regdeur hulle lewens (Potgieter, 1994:59). Hendriks (2003:10) meen dat die situasie in veral die NG Kerk tans betreurenswaardig is weens die onvermoë van ouer lidmate om by veranderings aan te pas. Inligting wat deur Kerkspieël (Kerklike aanvaarding, 2004:14) verskaf is, toon dat ouer 
kerkraadslede minder positief voel oor die kerklike aanvaarding van ander lede van die NGK-familie.

\subsection{Geslag}

Die gedagte dat vroue oor die algemeen meer godsdienstig is, word beskou as 'n vasstaande waarheid, hoofsaaklik gebaseer op studies wat in die Christelike konteks uitgevoer is. Vroue se religieuse ervarings en waardes verskil kwalitatief van dié van mans. Navorsing oor geslagsverskille met betrekking tot die beeld van God dui aan dat mans God in terme van mag, status en aansien beskou. In teenstelling hiermee sien vroue God as liefdevol, vertroostend en vergewensgesind (Kirkpatrick, 1999:946).

\subsection{Huwelikstatus}

Alhoewel daar in die literatuur geen verband gevind word tussen huwelikstatus en die houding oor kerkvereniging nie, gaan daar nietemin ondersoek ingestel word na so 'n moontlike verband.

\subsection{Kerklike betrokkenheid}

Empiriese navorsing toon dat die groei van 'n gemeente, die behoud van die jeug en die bemagtiging van lidmate afhang van sinvolle gemeenskapsbetrokkenheid. Die sukses van kerkwees word egter nie net bepaal deur kerklike betrokkenheid en die aanpak van projekte nie. Navorsing deur De Wet (Anon., 2004b:9) onder leiding van die Dekaan van die Fakulteit Teologie aan die Universiteit van Pretoria, het bevind dat om geloof in die hedendaagse samelewing uit te dra, 'n herwinning van Bybelse simbole vereis - iets wat aanleiding kan gee tot gemeenskaplike geloofsaktiwiteite. Volgens Kerkspieël is kerkraadslede, in vergelyking met predikante, minder positief oor die vooruitsig om ander mense uit die NGK-familie as lidmate te aanvaar (Kerklike aanvaarding, 2004:14).

\section{Navorsingsmetode}

\subsection{Navorsingshipoteses}

\subsubsection{Hipotese 1}

Lidmate van verskillende kerkverbande binne die NGK-familie verskil beduidend van mekaar met betrekking tot hulle houding teenoor kerkvereniging. 


\subsubsection{Hipotese 2}

Daar is beduidende verskille tussen kerklidmate se houding teenoor kerkvereniging, wat met huistaal, geslag, ouderdom, huwelikstatus en kerklike betrokkenheid in verband gebring kan word.

\subsection{Metode van ondersoek}

\subsubsection{Navorsingsontwerp}

'n Vraelysontwerp word gebruik om die navorsingsdoelwitte te bereik. Die spesifieke ontwerp heet die kruis-seksionele ontwerp: 'n steekproef van die gekose populasie word op 'n spesifieke tydstip getrek. Hierdie ontwerp is ideaal vir die beskrywende en voorspellende funksies wat met ex post facto-navorsing, geassosieer word. Dit behels dat daar nóg 'n eksperimentele ingreep, nóg 'n ewekansige toewysing plaasgevind het. Die gekose proefpersone het reeds voor die aanvang van die studie aan die verskillende vlakke van die onafhanklike veranderlikes behoort (Huysamen, 1993:27).

\subsubsection{Die steekproef}

Die steekproef is saamgestel uit lidmate van vier NGKA-gemeentes, ses VGK-gemeentes en ses NGK-gemeentes uit verskillende woongebiede, om die verteenwoordigendheid van die steekproef te verhoog. In die gebied waarop die artikel betrekking het, naamlik die Mangaung-area, is daar nie 'n Reformed Church in Africa nie. Dus sal die studie net van toepassing wees op die eersgenoemde kerkverbande binne die NGK-familie. Altesaam 400 vraelyste is vir verspreiding aangebied, waarvan 223 ingevorder en vir ontleding gekodeer is. Die totaal van 223 vraelyste het bestaan uit $47(21,1 \%)$ van die VGK, 72 (32,3\%) van die NGKA en 104 (46,6\%) van die NGK. Hieruit kan afgelei word dat die VGK nie goed verteenwoordig is nie - dit het beduidende gevolge vir die resultate.

\subsubsection{Meetinstrumente}

'n Gestruktureerde vraelys bestaande uit drie afdelings is as hoofnavorsingsinstrument aangewend. Aangesien daar tans nie 'n vraelys bestaan wat lidmate se houding teenoor die vereniging van die NGK-familie bepaal nie, is 'n Likert-houdingskaal bestaande uit drie subskale saamgestel. Die eerste twee subskale verteenwoordig 'n wysiging van die rolvoorskrifte vir die predikant-vraelys wat deur Potgieter (1994:89-90) opgestel is. Die eerste subskaal handel oor die prediking. Dit meet die respondent se houding ten opsigte van 
wat van prediking in 'n oorgangsfase na 'n geïntegreerde kerk verwag kan word. Die tweede subskaal ondersoek die verwagtings wat respondente moontlik koester oor die kerk se rol ten opsigte van geïntegreerde eredienste. Die derde skaal is deur die navorsers self ontwerp en meet respondente se houding jeens kerkvereniging as sodanig. Die hoogste telling wat 'n proefpersoon met verwysing na die voltooide vraelys kon behaal, was 124, terwyl die laagste moontlike telling 31 was, met 'n teoretiese gemiddeld van 77,5. Tellings hoër as die teoretiese gemiddeld dui op 'n positiewe houding, terwyl laer tellings 'n negatiewe houding weerspieël. 'n Biografiese vraelys is ook deur elke respondent voltooi.

\subsubsection{Betroubaarheid}

Cronbach se alfa-koëffisiënt is gebruik om die betroubaarheid van die houdingskale vas te stel. Die betroubaarheid van die eerste twee subskale is uitstekend. Die interkorrelasies tussen die skale is ook hoogs beduidend.

\subsubsection{Statistiese ontleding}

Meerveranderlike-variansie-ontleding, wat die interaktiewe en onafhanklike uitwerking van twee of meer onafhanklike veranderlikes op 'n aantal afhanklike veranderlikes meet, is op die data uitgevoer. Die onafhanklike veranderlikes is kerkverband (Hipotese 1) en huistaal, ouderdom, geslag, huwelikstatus en kerklike betrokkenheid (Hipotese 2), terwyl die afhanklike veranderlike die houding jeens kerkvereniging verteenwoordig. Cohen se dtoets vir praktiese beduidendheid is ook aangewend. Waar nodig is eenrigting-variansie-ontledings op die veranderlikes wat beduidend was, uitgevoer. Indien die F-toets beduidend is, word 'n post hoc Scheffé-toets gebruik om die bepaalde vergelykings wat wél beduidend van nul verskil, op te spoor.

\section{Resultate}

\subsection{Hipotese 1}

Hipotese 1 (sien 6.1.1) postuleer dat lidmate van die verskillende kerkverbande binne die NGK-familie beduidend van mekaar verskil met betrekking tot hulle houding teenoor kerkvereniging.

Die resultate wat met die meerveranderlike-variansie-ontleding verkry is, toon aan dat kerkverband as onafhanklike veranderlike die afhanklike veranderlike (houding jeens kerkvereniging) hoogs 
beduidend beïnvloed. Gevolglik is eenrigting-variansie-ontleding uitgevoer op elkeen van die subskale met kerkverband as onafhanklike veranderlike. Die eenrigting-variansie-ontleding vir al die subskale, naamlik prediking, eredienste en kerkvereniging, was hoogs beduidend. 'n Post hoc Scheffé-toets is uitgevoer om te bepaal watter groepe beduidend van mekaar verskil.

Volgens die post hoc Scheffé-toets wat uitgevoer is, verskil NGKlidmate se gemiddelde tellings op al drie skale beduidend van dié van die NGKA en die VGK. Laasgenoemde twee groepe se gemiddelde tellings verskil ook beduidend van mekaar ten opsigte van prediking. Dit moet in gedagte gehou word dat al drie die groepe se gemiddeldes hoër as die teoretiese gemiddeldes is (sien interpretasie van meetinstrument onder 6.2.3), wat dui op 'n positiewe houding teenoor kerkvereniging vir al drie groepe afsonderlik.

\subsection{Hipotese 2}

Die navorsingshipotese wat in 6.1.2 geformuleer is, postuleer dat beduidende verskille tussen kerklidmate se houding teenoor kerkvereniging heers, wat met huistaal, geslag, ouderdom, huwelikstatus en kerklike betrokkenheid in verband gebring kan word.

Die resultate van die meerveranderlike-variansie-ontledings wat uitgevoer is om dié navorsingshipotese te toets, toon dat sowel huistaal as kerklike betrokkenheid, volgens Cohen se d-toets, as onafhanklike veranderlikes oor matige praktiese beduidendheid beskik. Die eenrigting-variansie-ontleding wat uitgevoer is om die invloed van kerklike betrokkenheid te ondersoek, was nie beduidend nie. In teenstelling hiermee was die eenrigting-variansie-ontleding met taal as onafhanklike veranderlike beduidend vir prediking, eredienste en kerkvereniging. 'n Post hoc Scheffé-toets is uitgevoer om te bepaal watter groepe beduidend van mekaar verskil.

Uit die resultate van die Scheffé-toets blyk dat die enigste beduidende verskil dié tussen Afrikaanssprekendes en Sothosprekendes is. Afrikaanssprekendes se gemiddelde houdingstelling teenoor kerkvereniging is beduidend laer (hoewel steeds positief) as dié van Sotho-sprekendes. Die ander groepe verskil nie beduidend van mekaar nie. Daar moet egter ook vermeld word dat Afrikaanssprekendes en Sotho-sprekendes die enigste goed verteenwoordigde taalgroepe in die steekproef was. Daar moet dus nie te veel klem geplaas word op die feit dat die verskille tussen 
Afrikaanssprekendes en die ander taalgroepe nie beduidend was nie. Verder moet daarop gelet word dat die NGK en die VGK oorwegend Afrikaanse kerke is. Die bevolkingsverspreiding is ook van so 'n aard dat Sotho's die oorgrote meerderheid van die bevolking in die Mangaung-area uitmaak.

\section{Gevolgtrekking}

In hierdie artikel is gepoog om vanuit 'n sosiaal-psigologiese oogpunt kruiskultureel ondersoek in te stel na kerklidmate se houding teenoor kerkvereniging. Die sosiaal-psigologiese perspektief fokus op die neiging om mense met verwysing na binneen buitegroepe te klassifiseer, wat daartoe aanleiding gee dat gedrag aangepas word in ooreenstemming met hierdie klassifikasie (Kirkpatrick, 1999:930). In die Suid-Afrikaanse konteks kon tot dusver geen studie opgespoor word wat dieselfde oogmerke gehad het nie. Daar is dus 'n leemte in die bestaande literatuur en dit moet deurgaans in gedagte gehou word.

\subsection{Hipotese 1 (sien 5.1.1)}

Die belangrikste bevindings van die studie is dat lidmate van die NGK-familie deurgaans 'n positiewe houding openbaar teenoor kerkvereniging, alhoewel lidmate van die VGK se houding beduidend positiewer is as dié van die NGKA, waarvan die lidmate se houding weer positiewer is as dié van lidmate van die NGK. Wanneer na die ondersoek in die geheel gekyk word, word 'n positiewe houding teenoor kerkvereniging aangetref, wat verblydend is vir die kerk van Christus. In Hom is ons immers een. Geen twyfel oor die verwerkliking van die eenheid van die kerk kan bestaan nie. Die Bybel praat oor die kerk as die liggaam van Christus in 'n enkelvoudige sin. Eenheid lei tot verskeidenheid, maar dit vloei voort uit die eenheid en staan nie daarteenoor nie (Hofmeyr, 1996:336).

Vanuit 'n sosiaal-psigologiese perspektief lyk dit of die NGK se gedrag primêr gemotiveer word deur die begeerte om die eie kulturele waardes te bewaar. Alhoewel opregte bedoelings ten opsigte van optimale ontwikkeling vir alle bevolkingsgroepe binne hulle eie kulturele tradisie die dryfkrag agter die beleid van afsonderlike ontwikkeling was, het mededinging om skaars hulpbronne en politieke mag aanleiding gegee tot direkte antagonisme en konflik (Brewer, 1999:435; Potgieter, 1994:24-25). Wat is, was reeds; wat kom, was ook reeds. Alhoewel lidmate van die NGK van binnegroeplede na buitegroeplede verander het, word steeds meegeding om skaars hulpbronne en politieke mag. Dit kan 
moontlik 'n invloed uitoefen op die evaluering van die teenoorgestelde groep, met dien verstande dat negatiewe evaluering nie noodwendig tot direkte antagonisme en konflik lei nie (Brewer, 1999:435).

In die lig van bogenoemde kan Hipotese 1 dus aanvaar word. Hierdie hipotese postuleer dat die verskillende kerkverbande beduidend van mekaar verskil met betrekking tot hulle houding teenoor kerkvereniging. Dit is inderdaad so bevind.

\subsection{Hipotese 2 (sien 5.1.2)}

Dit het geblyk dat huistaal die enigste veranderlike is wat 'n beduidende invloed op die afhanklike veranderlike uitoefen. Die taalgroepe as geheel vertoon 'n positiewe houding. Alhoewel die houdings van Afrikaanssprekende lidmate, wat verskeie rassegroepe insluit, teenoor geïntegreerde eredienste, verwagtings oor prediking tydens die oorgangsfase na 'n geïntegreerde kerk en kerkvereniging as sodanig, beduidend minder positief is as dié van Sotho-sprekendes, is dit steeds positief. Aangesien daar 'n beduidende verskil tussen kerklidmate se houding teenoor kerkvereniging is wanneer dit met huistaal in verband gebring word, word die navorsingshipotese gedeeltelik aanvaar. Met behulp van die meetinstrument (sien 6.2.3) kan die volgende afgelei word:

Sotho-sprekendes se houding teenoor die kerk se rol in die bewerkstelliging van geïntegreerde eredienste is beduidend positiewer as dié van die Afrikaanssprekendes. Eersgenoemdes neem 'n positiewer houding in teenoor inisiatiewe soos die uitnooi van 'n anderskleurige koor na eredienste, sowel as die voorbereiding van lidmate op die waarskynlikheid van 'n meer geïntegreerde NGK (Potgieter, 1994:120). Afrikaanssprekendes het ook 'n laer telling ten opsigte van die konsekwente deurtrek van riglyne in die Woord om die prediking meer aktueel te maak. Dit behels onder andere wat die Woord sê oor die volgende sake: menseregte, vrede en versoening, die Christen se aanvaarding van alle mense se gelykwaardigheid ongeag kleur, en vele meer (Potgieter, 1994:118). Volgens Du Plessis (2004:5) spreek leraars nie tot mense binne die konteks van hulle eie leefwêreld nie, met die gevolg dat die prediking bloot ervaar word as 'n teologiese lesing wat glad nie grond vat in die lidmate se wêreld waar moreel-etiese besluite geneem moet word nie. Martin Luther het gesê: "If you preach the Gospel in all aspects with the exception of the issues which deal specifically with your time, you are not preaching the Gospel at all" (Cassidy, 1989:224). Sotho-sprekendes se houding 
teenoor kerkvereniging is beduidend positiewer as dié van die ander taalgroepe.

Taal dra nie net betekenis oor nie, dit dra ook gevoelens oor. Die manier waarop taal aangewend word, skep 'n bepaalde atmosfeer en dit is medebepalend vir die betekenisinhoude wat oorgedra word (Du Plessis, 2004:113).

Geen statisties beduidende verskille is ten opsigte van die invloed van geslag, ouderdom, huwelikstatus en kerklike betrokkenheid gevind nie. Alhoewel die bestaande literatuur toon dat geslag wel 'n invloed uitoefen op die wyse waarop God beskou word, naamlik as 'n magsimbool in teenstelling met 'n God wat liefdevol is (Kirkpatrick, 1999:946), het hierdie studie geen verskille gevind wat geslag betref nie. Ouderdom as veranderlike het ook geen invloed uitgeoefen op lidmate se houding teenoor kerkvereniging nie, alhoewel navorsers beweer dat ouer lidmate nie altyd oor die vermoë beskik om by veranderende omstandighede aan te pas nie (Hendriks, 2003:10).

Die kerk bestaan uit mense wat eenheid in 'n geloofsgemeenskap moet verwesenlik; dit bestaan uit mense wat aan Christus behoort en wat sy Woord warm in hulle harte voel brand. Die kinders van die Here word saamgebind in 'n eenheid deur die kruis en die opstanding van Christus en nie deur 'n organisasie nie. Hierdie eenheid word sigbaar gemaak deur die simboliek van geloof, aanbidding, bediening en die gesamentlike wag op die koms van Jesus. Die kerk van Christus is deur die bloed van martelare gebou. Kerkvereniging in die NGK-familie is imperatief en ' $n$ prinsipieel verdedigbare uitdaging. Vir kerke wat in ' $n$ mindere of meerdere mate onervare is as dit by kerkvereniging kom, hou dit sekerlik frustrasie en moedeloosheid in. Die weg na 'n meer verenigde NGKfamilie is vol uitdagings, maar terselfdertyd is die geleenthede geweldig groot (Hofmeyr, 1996:334).

Hierdie navorsingsartikel word afgesluit met Desmond Tutu se reaksie toe die verslag van die Waarheids-en-versoeningskommissie aan die President oorhandig is:

We have been wounded but we are being healed. It is possible even with our past of suffering, anguish, and violence to become one people, reconciled, healed, caring, compassionate and ready to share as we put our past behind us, to stride into the glorious future God holds before us as the Rainbow People of God (Meiring, 1999:388). 


\section{Tekortkomings en aanbevelings}

$\mathrm{Na}$ aanleiding van hierdie navorsing kan die volgende kritiekpunte en gepaardgaande aanbevelings gemaak word:

- Slegs lidmate van die NGK-familie in die Mangaung-area is ingesluit in die steekproef. Dit is dus nie moontlik om die resultate na alle lidmate van die NGK-familie in Suid-Afrika te veralgemeen nie. Daar word dus aanbeveel dat die steekproef uitgebrei, en waar moontlik, vergroot word.

- As gevolg van die lae responskoers van respondente is die verteenwoordigendheid van die resultate ingekort/aangetas. Die veralgemening van resultate moet dus met omsigtigheid hanteer word.

- Weens administratiewe oorwegings kon die vraelys slegs in Afrikaans en Engels vertaal word. Vir toekomstige gebruik word aanbeveel dat die vraelys ook in ander tale beskikbaar gestel word.

\section{Geraadpleegde bronne}

ADONIS, C. 2002. Bevryding tot eenwording en getuienis: die geskiedenis van die Verenigende Gereformeerde Kerk in Suider-Afrika 1950-2001. Nederduitse Gereformeerde teologiese tydskrif, 43:327-341.

ANON. 2003. Versoening. Die Kerkbode: 6, 8 Aug.

ANON. 2004a. Nuwe energie vir kerkhereniging. Die Kerkbode: 6, 12 Nov.

ANON. 2004b. Moue op. Die Kerkbode: 9, 25 Jun.

BARNARD, A.C. 1981. Die erediens. Pretoria: NG Kerkboekhandel.

BREWER, M.B. 1999. The psychology of prejudice: ingroup love or outgroup hate? Journal of social issues, 55:429-444.

CASSIDY, M. 1989. The passing summer: a South African pilgrimage in the politics of love. Londen: Hodder \& Stoughton.

COERTZEN, P. 2000. The unity of the family of Dutch Reformed Churches in South Africa: then and now - prospects and frustrations: a Dutch Reformed perspective. Nederduitse Gereformeerde teologiese tydskrif, 41:179-195.

COETZEE, S. 2004. Beslissende tyd vir die NG Kerk-familie. Die Kerkbode: 7, 12 Nov.

DU PLESSIS, I. 2004. Multisensoriese liturgie. Pretoria: Universiteit van Pretoria. (M.A.-verhandeling.)

EAGLY, A. \& CHAIKEN, S. 1993. The psychology of attitudes. New York: Harcourt Brace.

HENDRIKS, J. 2003. Die toekoms van die kerk, die kerk van die toekoms. Stellenbosch: Universiteit van Stellenbosch.

HOFMEYR, J.W. 1996. Kerkvereniging en kerkreg: geskiedenis, beginsel en praktyk. Skrif en kerk, 17:329-346. 
HUYSAMEN, G.K. 1993. Metodologie vir die sosiale en gedragswetenskappe. Johannesburg: International Thomson.

JACKSON, L.M. \& HUNSBERGER, B. 1999. An intergroup perspective on religion and prejudice. Journal for the scientific study of religion, 38:509523.

JONKER, W. 1998. Kragvelde binne die kerk. Aambeeld, 26:11-14.

KERKLIKE AANVAARDING: ENKELE OPMERKINGS UIT DIE KERKSPIEËL. 2004. http://www.gemeentes.co.za/pdf/kerklike\%20aanvaarding/pdf\#searc $\mathrm{h}=\%$ c3\%ABI\%22 Datum van gebruik: 7 Sept. 2006.

KIRKPATRICK, L.A. 1999. Towards an evolutionary psychology of religion and personality. Journal of personality, 67:921-952.

KIRKPATRICK, L.A. \& HOOD, R.W. 1990. Intrinsic-extrinsic religious orientation: the boom or bane of contemporary psychology of religion? Journal for the scientific study of religion, 29:442-462.

MEIRING, P. 1999. Kroniek van die Waarheidskommissie. Vanderbijlpark: Carpe Diem.

NEDERDUITSE GEREFORMEERDE KERK. 1974. Ras, volk en nasie en volkereverhoudinge in die lig van die Skrif: beleidstuk goedgekeur deur die Algemene sinode van die Nederduitse Gereformeerde Kerk, Oktober 1974. Kaapstad: NG Kerk Uitgewers.

NEDERDUITSE GEREFORMEERDE KERK. 1986. Kerk en samelewing: 'n getuienis van die Nederduitse Gereformeerde Kerk soos aanvaar deur die Algemene sinode van die Nederduitse Gereformeerde Kerk. Bloemfontein: NG Sendingpers.

NEDERDUITSE GEREFORMEERDE KERK. 1990. Kerk en samelewing: 'n getuienis van die Nederduitse Gereformeerde Kerk soos aanvaar deur die Algemene sinode van die Nederduitse Gereformeerde Kerk. Bloemfontein: NG Sendingpers.

NEDERDUITSE GEREFORMEERDE KERK: Algemene sinode. 1994. Acta NGK synodi.

kyk NEDERDUITSE GEREFORMEERDE KERK

NEL, A. 2003. Op soek na God buite die kerk? Wen weer ontnugterde gelowiges se vertroue. Wellington: Lux Verbi.BM.

OOSTHUIZEN, J. 2003. Deurbraak vir eenheid. Kerkbode: 6, 7 Feb.

OOSTHUIZEN, J. 2004a. NG Kerk ontken rassisme. Die Kerkbode: 1, 2 Feb.

OOSTHUIZEN, J. 2004b. VGK is nie dwars nie, sê Buys. Die Kerkbode: 3, 26 Nov.

OOSTHUIZEN, J. 2004c. Eenheid: nuwe wending. Die Kerkbode: 1, 13 Feb.

PLUG, C., LOUW, D.A.P., GOUWS, L.A. \& MEYER, W.F. 1997. Verklarende en vertalende sielkundewoordeboek. Johannesburg: Heinemann.

POTGIETER, A.V. 1994. Rolvoorskrifte vir die predikant in die oorgangsfase na 'n geïntegreerde gemeenskap en gemeente. Bloemfontein: Universiteit van die Vrystaat. (M.A.-verhandeling.)

ROBBINS, S.P. 1998. Organizational behavior. 8th ed. New Jersey: Prentice Hall.

SAUER, D. 2005. NGK “reeds aan't skeur": VS-moderator reageer op berigte. Volksblad: 1, 16 Mei.

SCHIFFMAN, L.G. \& KANUK, L.L. 1997. Consumer behavior. 6th ed. New Jersey: Prentice Hall. 
SMITH, N.J. 1972. Die planting van afsonderlike kerke vir nie-blanke bevolkingsgroepe deur die Nederduitse Gereformeerde Kerke in SuidAfrika. Bloemfontein: Universiteit van die Vrystaat. (D.-proefskrif.)

STEPHAN, C.W. \& STEPHAN, W.G. 1990. Two social psychologies. 2nd ed Belmont: Wadsworth Thompson Learning.

STRAUSS, P.J. 2005. Belydenis, kerkverband en Belhar. Ongepubliseerde artikel.

TAYLOR, S.F., PEPLAU, L.A. \& SEARS, D.O. 2003. Social psychology. 11th ed. New Jersey: Prentice Hall.

VAN DER LINDE, H.H. 2002. 'n Kerkhistoriese en kerkregtelike studie van die kerkverenigingsproses in die Nederduitse Gereformeerde Kerkfamilie. Universiteit van Pretoria. (D.-proefskrif.)

VAN DER MERWE, J.M. 1990. "Ras, volk en nasie" en "Kerk en samelewing" as beleidstukke van die Nederduitse Gereformeerde Kerk: 'n kerkhistoriese studie. Universiteit van Pretoria. (D.-proefskrif.)

VAN NIEKERK, A.C.J. 1996. Moet ons die belydenis van Belhar (1986) as 'n nuwe belydenisskrif aanvaar? Skrif en kerk, 17:443-455.

VAN ROOYEN, H. 2002. 'n Kruiskulturele ondersoek na voorspellers van jong volwasse studente se houdings teenoor die huwelik. Universiteit van die Vrystaat. (M.A.-verhandeling.)

WEITEN, W. 2002. Psychological themes and variations. 5th ed. California: Wadsworth Thompson Learning.

WESSELS, F. 2004. Kerkvereniging en Belhar. Die Kerkbode: 9, 8 Okt.

WORCHEL, S., COOPER, J., GOETHALS, G.R. \& OLSON, J.M. 2000. Social psychology. Belmont: Wadsworth Thompson Learning.

\section{Kernbegrippe:}

aparte ontwikkeling

houding teenoor kerkvereniging

huistaal

kerkvereniging

\section{Key concepts:}

attitude towards church unification

church unification

home language

separate development 